日薬理誌 $66,435 \sim 441$ (1970)

\title{
動物群集心理学の薬理学への導入一 5
}

E1- マゥスの運動，性差または刺激時刻と痙卛発症の関係

\author{
秦 多恵子, 村上 哲男, 喜多富太郎 \\ (近畿大学薬学部薬理学教室) \\ (昭和 45 年 4 月 4 日受付〔特〕)
}

\begin{abstract}
緒
言

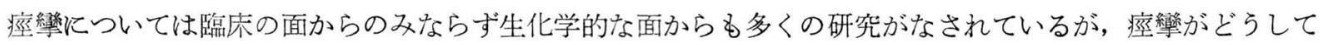
起こるのか, 病攣誘発の要因やその生物学的意義などについてはまだはっきりしない点が多い.

そこで痤卛を本質的な面から理解するためには，薬物や電気剌激などによる痤攣よりもむしろ遺伝的素質と して僅かな刺激により痤變を起こし易いE1-マウスの痤變を対象として研究する方がより望ましいと考えて以下 種々の実験を試みた。

われわれは先に E1-マウス痙攣発症の相互関係について2，3の実験を試み，ある時期には 2 匹を同時に振 とらすると痤彎発症まで㴗する振とう回数（振とう痤攣閾值 threshold of shaking-number for convulsion, 以下 TSC と略す) は1匹のみ振とうした時の TSC より著しく小さくなり，3匹を同時に振とうするとその中

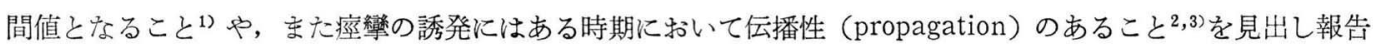
してきた，続いて今回は E1-マウス痤卛発症の諸要因についてマウスの性差, 振とら刺激を与兄る時刻と痤卛発 症の関係などを検討したので報告する.
\end{abstract}

\section{実験動物と実験方法}

動物は10週令以上の E1-F-30 系統のマウスで，60回以内の振とう刺激で確実に痙卛を起こすもの 140 匹を 2〜4 日置きに反覆使用した。振とう剌激としては厚紙製平箱を用いて頻度 $104 \mathrm{cycle} / \mathrm{m}$, 高さ $10 〜 15 \mathrm{~cm} の$ 放り上げ運動を行なった，振とう回数60回に達しても病卛発症の見られないものは不発作とし，不発作マウスの 全実験匹数に対する百分率を不発作率 (rate of non-convulsion) とした. また 2 〜 匹を同時に振とうした時 TSC の差が 5 以内であればその 2 匹または 3 匹間に痤彎誘発の同調性 (Simultaneity) があるとした.

\section{実 験 成 績}

\section{El-マウス痮采に対する振とう運動の影響}

E1-マウスに振とう刺激（ほらり上げ運動）を与えると痤攣発作が見られるが，この際マウスが痤卛を起こ し始めてから振とうを止めた場合と, 症攣を起こしてもなおそのまま振とうし続けた場合とについて, 一連の痤 攣発作の各時期に和ける持続時間を比較した。 これを Fig. 1 亿示す.

Fig. 1 中 $\square$ は痤攣発症後振とう刺激を止めた場合 (A), I/ は発症後もなお振とう刺激を加えた場 合（B）の成績を示す.

E1 痤變の発症の様子を一応図の下に示したように区分して整理してみた。すなわち平箱上で El-マウスに 放り上げ運動を行なった場合 (shake), 20〜30回振とらすると El-マウス特有の疗攣を起こし始め (beginning), 大多数のマウスは $2 \sim 3^{\mathrm{s}}$ 後横転する (tumble). しばらく後起き上る (rise) が, その後もな和顔面や前肢にか なり激しい痤攣が見られ，それがおさまると後㾏攣昏睡期 (postictal coma) に移行する. 


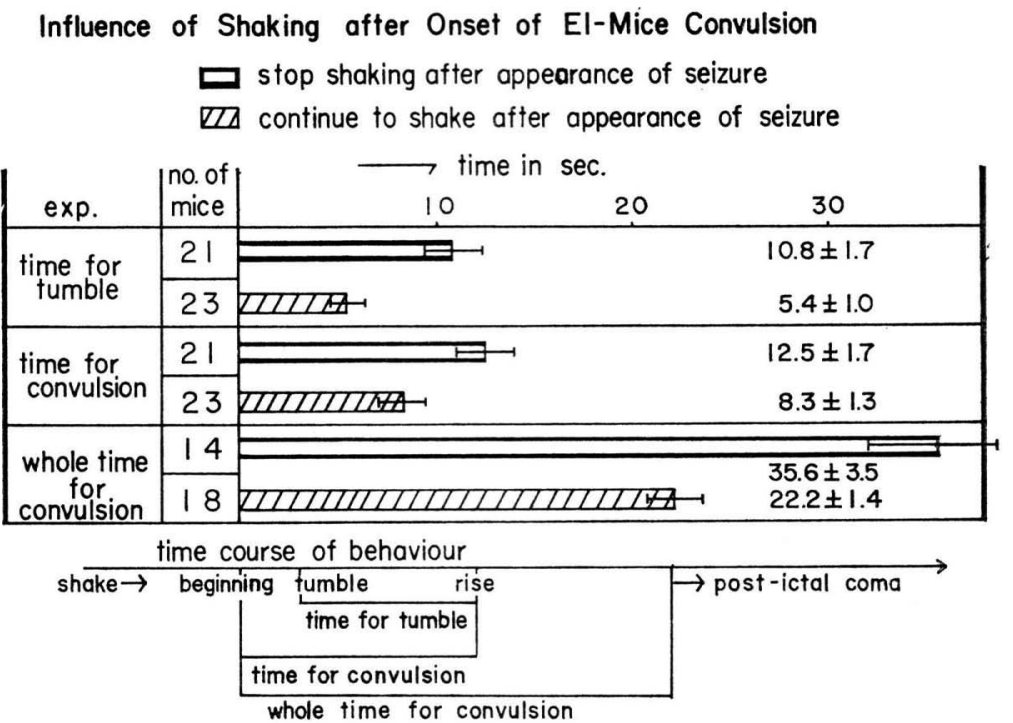

Fig. 1

Fig. 1 の成績によると，倒れてから起き上るまでの時間（横転時間）はAの場合 10.8土1.7（秒単位，以 下同様)であるが，Bでは $5.4 \pm 1.0$ とかなり短くなっている。また痦攣開始時から倒孔として起き上るまでの 時間についてはAは $12.5 \pm 1.7$, B $8.3 \pm 1.3$, 噔卛開始時より postictal coma に入るまでの時間もAは $35.6 \pm 3.5$, Bは 22.2 11.4 であり, 以上三つのいずれの時期で見た場合も, 発作後な利振とうし続けた場合の 方が痤攣持続時間が短くなっている。このことは台らの言うように運動は症攣に対し抑制的に働くという見解を 側面から支持するるのと思われる。

\section{III.TSC に及ぼす時間的影響ならびに性差}

E1-マウスを一匹のみ，あるいは 2 匹または 3 匹を1群として同時に振とうした場合の TSC 拈よび不発作 率をいくつかの場合について比較した。まず倠雄の差について Fig. 2 に示す。

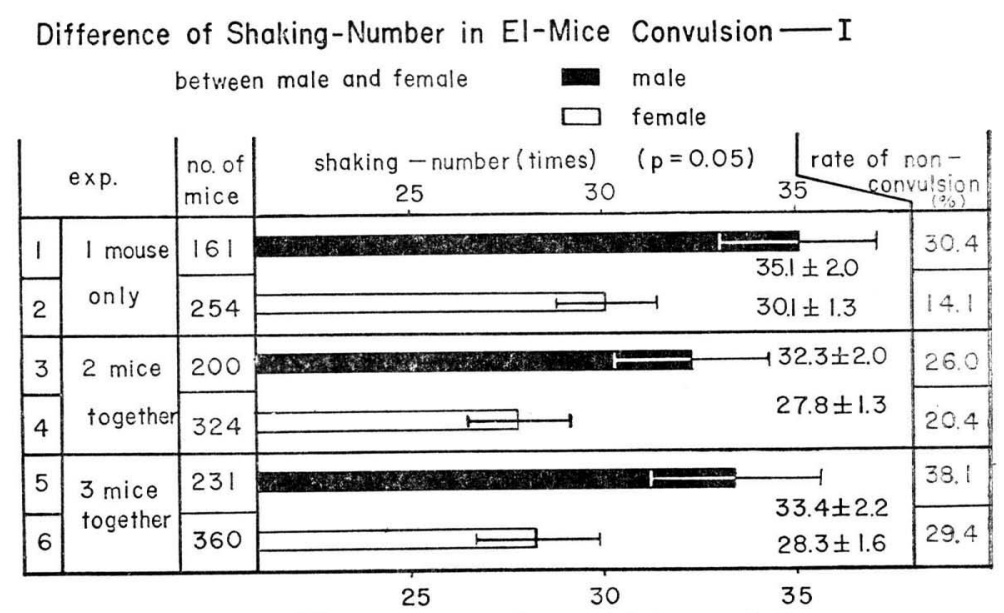

Significant differences were observed between follows:

exp. $1-2,3-4,5-6,1-3,2-4$.

Fig. 2 
Fig. 2 によれば1匹の振とうした時の TSC は雄では $35.1 \pm 2.0$ であり, 雌では $30.1 \pm 1.3$ で雄より閾 值が小さく, 2 匹同時振とうでは雄は $32.3 \pm 2.0$, 雌は $27.8 \pm 1.3,3$ 匹同時振とうでは雄は $33.4 \pm 2.2$, 雌は $28.3 \pm 1.6$ で, いずれも雌の方がかなり小さな值であった.

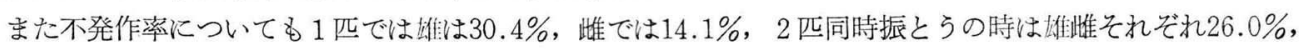
20.4\%，3 匹同時振とうではそれぞれ $38.1 \% ， 29.4 \%$ となり，いずれも雌法ける不発作率の方が小さくなっ た.

以上のごとく雌は雄に比して TSC が小さく不発作率も小さいという2 つの事実より E1-マウスの痤戀は雄 より雌の方が起こり易いと思われる.

次に朝と夕刻という実験時刻によるTSC などの差異を調べたのが Fig. 3 である.

\section{Difference of Shaking-Number in El-Mice Convulsion - II \\ between at morning and at evening $\square$ at morning \\ एس at evening}

\begin{tabular}{|c|c|c|c|c|c|c|}
\hline \multirow{2}{*}{\multicolumn{2}{|c|}{ exp. }} & \multirow{2}{*}{$\begin{array}{l}\text { no. of } \\
\text { mice }\end{array}$} & shaking-nur & \multicolumn{2}{|c|}{$(p=0.05)$} & $\begin{array}{c}\text { rate of } \\
\text { non-convulsion }\end{array}$ \\
\hline & & & 30 & & 35 & \\
\hline \multirow{2}{*}{\begin{tabular}{|l|} 
\\
2
\end{tabular}} & \multirow{2}{*}{$\begin{array}{l}\text { I mouse } \\
\text { only }\end{array}$} & 217 & & \multirow{2}{*}{\multicolumn{2}{|c|}{$\begin{array}{l}\longrightarrow 2.8 \pm 1.5 \\
30.7 \pm 1.6\end{array}$}} & 19.8 \\
\hline & & 198 & 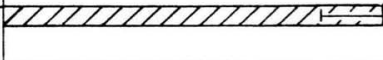 & & & 21.2 \\
\hline \multirow{2}{*}{\begin{tabular}{|l|}
3 \\
4 \\
\end{tabular}} & \multirow{2}{*}{$\begin{array}{l}2 \text { mice } \\
\text { together }\end{array}$} & 278 & \multirow{2}{*}{ 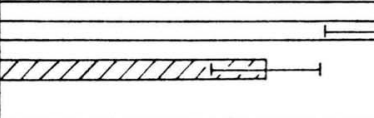 } & $\longrightarrow$ & \multirow{2}{*}{$\begin{array}{l}30.8 \pm 1.5 \\
27.8 \pm 1.4\end{array}$} & 20.5 \\
\hline & & 246 & & & & 24.8 \\
\hline \multirow{2}{*}{\begin{tabular}{|l|}
5 \\
6
\end{tabular}} & \multirow{2}{*}{$\begin{array}{l}3 \text { mice } \\
\text { together }\end{array}$} & 294 & \multirow{2}{*}{\multicolumn{2}{|c|}{ 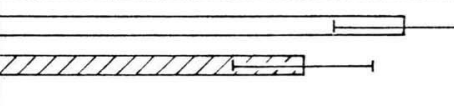 }} & & 32.7 \\
\hline & & 297 & & & $28.8 \pm 1.8$ & 22.9 \\
\hline
\end{tabular}

253535

Significant differences were observed between follows:

$\exp 3-4,5-6,2-4$.

Fig. 3

Fig. 3 に打いては $\square$ は午前 $10^{\mathrm{h}}$ 前後（以下，朝と記す）飞調べた結果を示し，【/ は午後 $5^{\mathrm{h}}$ 前後 (以下，タ刻と記す）に調べた結果を示している.

Fig. 3 によ机ば, 1匹のみ振とうした時あるいは 2 匹または 3 匹を同時に振とうした時のいずれの場合に も朝より夕刻における方が TSC が小さい。 また不発作率は1匹のみ振とうした時および 2 匹同時に振とうした

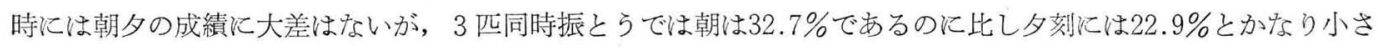
くなっている.

以上のごとく TSC および不発作率の面から見ると E1-マウスの痤戀は朝より夕刻の方が起こり易いように 思われる.

ついで朝あるいは夕刻に和ける雌婎の TSC などについての差を調べたものを Figs. 4, 5 に示す。

Fig. 4 は朝, Fig. 5 は夕刻に和壮る成績であり, 両図共に は雄, $\square$ は崔についての成績を示す。

Fig. 4 によれば, 朝では雄 1 匹, 2 匹， 3 匹の TSC の間には差異がなく, 雌の TSC 飞ついては 1, 2, 3 匹いずれの場合も雄のそれより小さく, 特に 2 匹同時振とうではかなり小さくなっている.

Fig. 5 より夕刻に特けるTSCについては朝の場合と近で, 雌は 1 匹のみ, 2 匹同時または 3 匹同時振とう に和ける TSC の間に大差なく, 雄では1匹のみ振とう時の TSC に比べ 2 匹同時振とうでの TSC はかなり

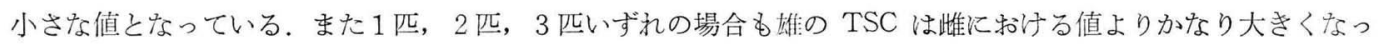
ている. 


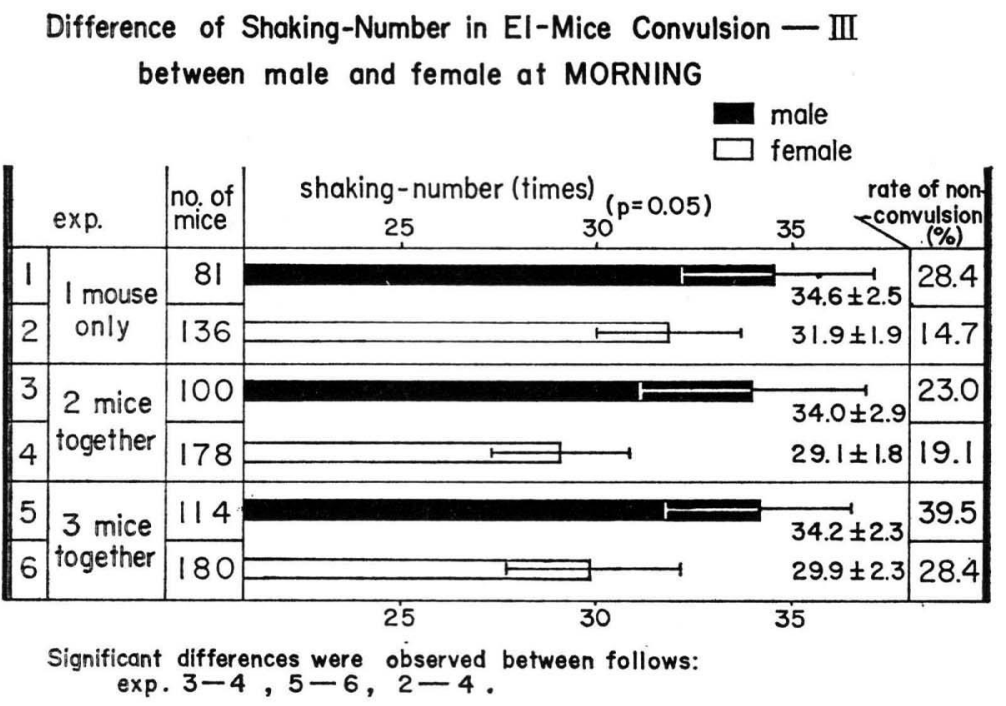

Fig. 4

\section{Difference of Shaking-Number in El-Mice Convulsion - TV between male and female at EVENING}

\begin{tabular}{|c|c|c|c|c|c|c|}
\hline & \multirow{2}{*}{ exp. } & \multirow[t]{2}{*}{$\begin{array}{l}\text { no.of } \\
\text { mice }\end{array}$} & shaking-number(times) & $(p=0.05)$ & $\begin{array}{l}\square \text { male } \\
\square \text { femal } \\
\text { hon-c }\end{array}$ & $\begin{array}{l}\text { te of } \\
\text { te olsion } \\
\text { ival }\end{array}$ \\
\hline & & & 25 & & 3.5 & \\
\hline 1 & \multirow{2}{*}{$\begin{array}{l}\text { I mouse } \\
\text { only }\end{array}$} & 80 & & & \multirow[b]{2}{*}{$\begin{array}{l}35.5 \pm 3.1 \\
28.1 \pm 1.6\end{array}$} & 32.5 \\
\hline 2 & & 118 & & & & $\mid 13.6$ \\
\hline \multirow[b]{2}{*}{4} & \multirow{2}{*}{$\begin{array}{l}2 \text { mice } \\
\text { to gether }\end{array}$} & 100 & $=$ & -1 & \multirow{2}{*}{$\begin{array}{l}30.3 \pm 2.6 \\
26.3 \pm 2.0\end{array}$} & 29.0 \\
\hline & & 146 & $\rightleftarrows$ & & & 21.9 \\
\hline \multirow[t]{2}{*}{5} & \multirow{2}{*}{$\begin{array}{l}3 \text { mice } \\
\text { fogether }\end{array}$} & 117 & & & \multirow{2}{*}{$\begin{array}{l}-1 \\
32.6 \pm 3.1 \\
26.7 \pm 2.2\end{array}$} & 36.8 \\
\hline & & 180 & & & & 25.0 \\
\hline
\end{tabular}

Significant differences were observed between follows: exp. $1-2,3-4,5-6,1-3$.

Fig. 5

Fig. 4 と Fig. 5 を比較してみると, 1 匹のみ振とうした時の TSC は朝では雌雄の間に有意差は認められ

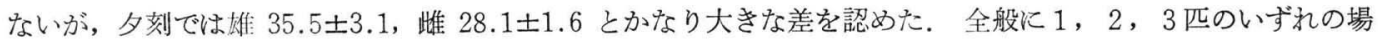
合についても, 朝でも夕刻でも雌雄の TSC 飞差は認められるが, その差は朝におけるより夕刻に括ける方がか なり大きいようである。

次に雌雄別に朝夕の比較を試みたのが Figs. 6, 7 である.

Fig. 6 は雄, Fig. 7 は雌について示している. 両図共に|】/が夕刻の成績である.

Fig. 6 飞よると雄では 2 匹同時振とうの場合の TSC は朝より夕刻に和ける方が少し小さくなっているが, 
Difference of Shaking-Number in El-Mice Convulsion - $\nabla$ between at morning and at evening in MALE mice

I $\square$ at morning

\begin{tabular}{|c|c|c|c|c|c|}
\hline \multicolumn{2}{|r|}{ exp. } & \multirow{2}{*}{\begin{tabular}{|c|}
$\begin{array}{l}\text { no. of } \\
\text { mice }\end{array}$ \\
81 \\
\end{tabular}} & $\begin{array}{cc}\text { shaking - number (times) } \\
25 \quad 30\end{array}$ & \multicolumn{2}{|c|}{$\begin{array}{c}\begin{array}{c}\text { rate of } \\
\text { non-convulsion } \\
(\%)\end{array} \\
\end{array}$} \\
\hline I & I mouse & & & & 28.4 \\
\hline 2 & & 80 & 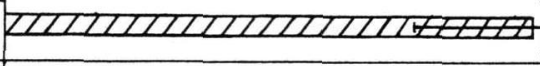 & $35.5 \pm 3.1$ & 32.5 \\
\hline 3 & 2 mice & 100 & & 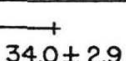 & 23.0 \\
\hline 4 & & 100 & 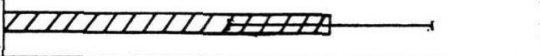 & $30.3 \pm 2.6$ & 29.0 \\
\hline 5 & 3 mice & 114 & & $34.2 \pm 2.3$ & 39.5 \\
\hline 6 & & 117 & $Z 7$ & $32.6 \pm 3.1$ & 36.8 \\
\hline
\end{tabular}

Significant difference was observed between exp. 2 and exp. 4 .

Fig. 6

\section{Difference of Shaking-Number in EI-Mice Convulsion-VT \\ between at morning and at evening in FEMALE mice}

$$
\text { \& at morning }
$$

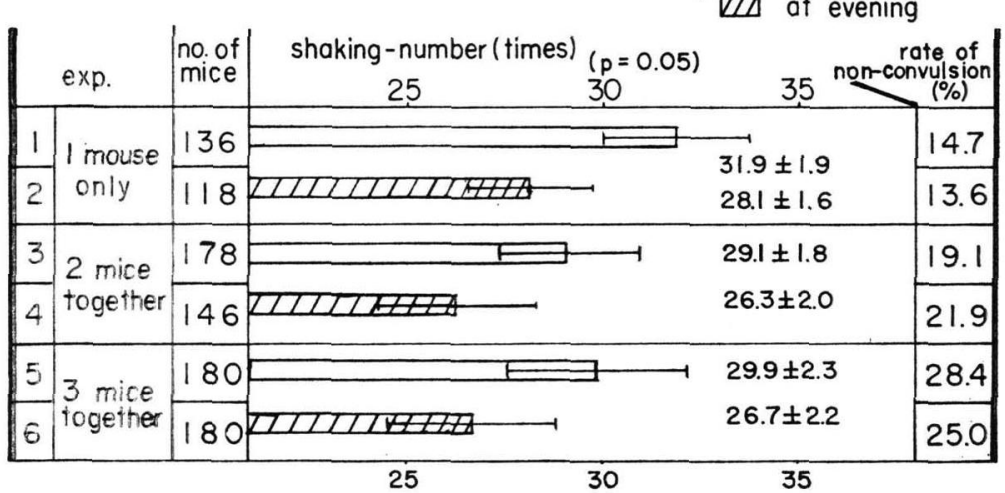

Significant differences were observed between follows: $\exp .1-2.3-4.5-6.1-3$.

Fig. 7

1 匹のみ振とうあるいは 3 匹同時振とうの時の TSC は朝夕に差は見られない.

Fig. 7 によると雌では 1 匹のみ振とうした時でもあるいは 2 匹または 3 匹を同時に振とうした時でも，い ずれも朝より夕刻に蚂ける方が TSC が小さくなっている.

不発作率については雌雄共に朝と夕刻に纱いて大差はなかった.

これら Figs. 6, 7 の成績より, TSC に関しては雄より雌の方が朝夕における差が大きくなっている.

以上の Figs. 2〜7 の成績より，TSC および不発作率の面から見た場合， E1-マウスを雌雄の別なく使用す る場合には, 夕刻より朝における方が性による差が小さく, 従って実験は午後よりもむしろ午前中に行なった方 がより均一な成績が得られるよらに思われる。 
III 同調性における性差

次に崔性ならびに雌性 E1-マウスに和ける同調性を比較してみた.

\section{Comparison of the Simultaneity in El-Mice Convulsion \\ between male and female

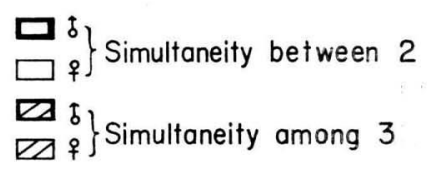

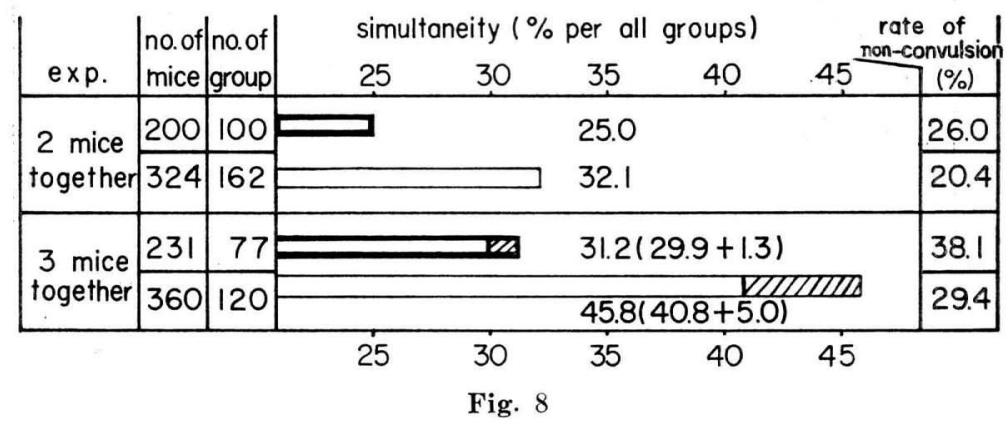

Fig. 8 は 2 匹または 3 匹を一緒に振とうした場合の同調率を示している。この図では同調した組数の全寒 験組数に滾する百分率を同調率として示している. 図中二は雄について, $\square$ は雌についての同調率を示 し，また斜線を入れた部分は 3 匹同時振とうの際に 3 匹全部が同調した組についての百分率を示している.

Fig. 8 によれば 2 匹同時振とうの場合の同調率は雄では25.0\%, 雌では32.1\%であった. 3 匹同時振とう の場合は雄では 3 匹の内 2 匹間に同調の見られた組は $29.9 \%, 3$ 匹全部同調した組が $1.3 \%$ で合計 $31.2 \%$ の同調 率であり, 雌では同様に $40.8+5.0=45.8 \%$ の組において同調が見られた.

このように 2 匹， 3 匹いずれの場合にも雄より雌の方が痤攣誘発の同調性が大となっている.

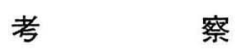

痤攣と運動との 関連性については，運動は痤攣を抑制するといら台らの報告があるが，詳しいものではな

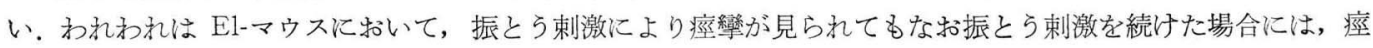
攣発症が見られた後は振とうを止めた場合に比べて痓卛持続時間が短くなるといら成績を得た。このことはやは り，運動は痤攣に対して抑制的に働いていることを側面から支持するものと思われる。

また El一マウスの痤變は雄より雌に和いて，また朝より夕刻飞执いて起り易く，さらに雌の方が同調し易い といら結果を得たが，これらのことから，El-マウスの痤攣誘発には性ホルモンも何らかの形で関与しているの ではないかとも思われ，また1日括ける痤攣誘発のバイオリズムの存在も教えられる。この問題については引 続き実験中である.

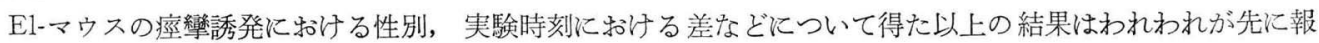
告次したところの, 年令, 性别飞無関係の長期に亘るバイオリズムの存在と共に, 痤攣を研究する際のみなら ず，一般に動物を报って実験を行うに祭しても大いに考虑しなければならない問題であると思われる.

要 約

E1-マウス痤攣発症の要因についていくつかの検討を加え, 次のような結果を得た. 
1）E1-マウスの痙攣発作出現後の運動（振とう剌激）は，痙卛に抑制的に働くようである.

2）El一マウスの痙攣は雄より雌の方が起こり易かった。

3）El-マウスの痙攣は午前中より夕刻の方が起こり易かった. 特に雌に和いてこの傾向が大であった.

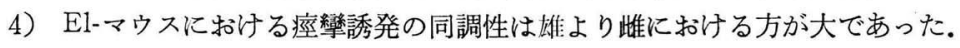

本論文の要旨は第42回日本薬理学会総会においてロ演発表した。

\section{文献}

1）喜多富太郎, 秦多恵子, 村上哲男 : 日薬理誌, 65,373 (1969), 65 (5)，166§ (1969).

2）喜多富太郎, 秦多恵子, 村上哲男 : 日薬理誌, 65 (5), $184 \S$ (1969).

3）秦多恵子, 村上哲男, 喜多富太郎：日薬理誌，65（5). $184 \S(1069)$. 